Sorodiscus on Pythium. Jour. Elisha Mitchell Sci. Soc. 67: 108-121.

IvimEY-Cook, W. R. 1932. An account of some uncommon British species of the Chytridiales found in algae. New Phytol. 31: 133-144.

1933. A monograph of the Plasmodiophorales. Arch. Protistenk. 80: 179-254.

AND W. H. Nicholson. 1933. A contribution to our knowledge of Woronina polycystis Cornu. Ann. Bot. 47: 851-859.

Karling, J. S. 1942a. The Plasmodiophorales. New York. 1942b. The simple holocarpic biflagellate Phycomycetes. New York.

Ledrngham, G. A. 1934. Zoospore ciliation in the Plasmodiophorales. Nature 133: 534.

1935. Occurrence of zoosporangia in Spongospora subterranea (Wallroth) Lagerheim. Nature 134: 394 .

1939. Studies on Polymyxa graminis, n. sp., a Plasmodiophoraceous root parasite of wheat. Canad. Jour. Res. C. 14: 38-51.

Minden, M. Von. 1911. Chytridiineae, Ancylistineae,
Monoblepharidineae, Saprolegniineae. Kryptogamenfl. Mark Brandenburg 5(2) : 193-352.

Pendergrass, W. R. 1948. A new member of the Plasmodiophoraceae. Jour. Elisha Mitchell Sci. Soc. 64: 132-134.

1950. Studies on a Plasmodiophoraceous parasite, Octomyxa brevilegniae. Mycologia 42: 279-289.

Pringsheim, N. 1860. Beiträge zur Morphologie und Systematik der Algen. Jahrb. Wiss. Bot. 2: 205-236.

Sparrow, F. K., JR. 1936. A contribution to our knowledge of the aquatic Phycomycetes of Great Britain. Jour. Linn. Soc. Bot. London 50: 417-478.

1942. A classification of aquatic Phycomycetes. Mycologia 34: 113.

. 1943. Aquatic Phycomycetes exclusive of the Saprolegniaceae and Pythium. Univ. Michigan Press. Ann Arbor.

Whiffen, Alma. 1939. The cytology of a new species of the Plasmodiophoraceae. (Abstract). Jour. Elisha Mitchell Sci. Soc. 55: 243.

Winge, Ö. 1913. Cytological studies in the Plasmodiophoraceae. Arkiv för Bot. 12(9) : 1-39.

\title{
FURTHER STUDIES ON THE GRAFTING OF MONOCOTYLEDONOUS PLANTS ${ }^{1}$
}

\author{
Thomas J. Muzik and Carl D. La Rue
}

Although THE GRAfting of dicotyledonous plants has been practiced for centuries, reports of successful grafting of monocotyledonous plants are very rare in the literature. The consensus of present day opinion seems to be that only dicotyledonous plants may be grafted. Eames and MacDaniels (1947) state that cambiums must be joined for successful union and Transeau et al. (1947) state that plants without cambiums cannot be grafted.

More than a hundred years ago Calderini (1846) reported that he grafted rice on barnyard grass. Without further statement this report is not beyond belief, but his claim that he harvested rice grains from which he grew a new strain of rice that showed some desirable characteristics of the barnyard grass makes the whole account appear dubious. Schubert (1913) gave a thorough review of the numerous attempts at grafting monocotyledons which had preceded his own numerous trials. He concluded that the problem remained unsolved; that he and his predecessors obtained nothing more than parenchymatous unions and that although scions sometimes survived for remarkable periods of time they eventually died without a true union.

Recent workers have achieved greater success. Plotnikov (1939) has grafted small grains. La Rue (1944) made grafts in Tradescantia, Zebrina and Commelina as well as intergeneric grafts be-

\footnotetext{
${ }^{1}$ Received for publication September 12, 1953.

Paper No. 1000 from the Department of Botany, University of Michigan.

The writers wish to thank Miss Elida Vivas of the Federal Experiment Station in Puerto Rico for making the microscopic slides used in this investigation.
}

tween these plants in which vascular connections were developed.

La Rue and Reissig (1946) found that dicotyledonous leaves grafted readily where callus formation could supply meristematic tissue for union. Leaf grafts have not yet been made in monocotyledons although one scion was found grafted to a leaf-sheath in Tradescantia. The work with leaves emphasized that a cambium is not an absolute requisite for grafting but a meristem is. A realization of the possibility of a graft union wherever meristems are present and the successful use of intercalary meristems led to attempts to make grafts in some of the larger plants in the monocotyledonous group. A preliminary account of some of this work has been published by Muzik and La Rue (1952). The present paper is concerned with presenting more pertinent detail as well as the supporting photographs for this and subsequent work.

MATERIALS AND METHODS.-It was assumed that the intercalary meristems in the larger grasses might serve for graft union. Most of the grasses have well defined intercalary meristems immediately above the nodes. To make a graft, a stem was grasped with one hand above a node and the other one below the node. A sharp tug broke the stem in the intercalary meristem region and within the leaf sheath. The cells in this region have weaker and thinner walls than those elsewhere in the stem, so the break was usually a clean one. If the node selected was too old, the intercalary meristematic region may have matured. If so, a younger node was selected. Sometimes a stem broke in the node itself and could not be used. If the upper stem broke off properly and slipped out of the leaf 
sheath, a scion was pulled out in the same way from another stem and pushed into the leaf sheath until it made firm contact with the broken end of the intercalary meristem of the stock. The scion was then tied in place with a cord around the top of the leaf sheath. It was found that unless the scion was tied firmly it was likely to be dislodged by elongation.

The lianas usually lack a true intercalary meristem and a leaf sheath but much of the stem for the first several internodes behind the tip of a rapidly growing plant is more or less meristematic. A variety of grafts was made, including inarches, cleft grafts, and bottle grafts. Another type of graft was made in which paper tubes dipped in paraffin were used as supports in place of leaf sheaths. The stem was broken and the tube slipped over the stock. The scion was then inserted and the tube was tied firmly at each end.

In all grafts, it was found extremely important to have scion and stock of exactly the same size, or the scion smaller; and to prune off sprouts from buds on the stock of frequent intervals. If the sprouts from the stock are allowed to grow the scions wither and die although firmly attached. Frequently also, unless cut off, buds from below the graft will crowd the scion and break the connection.

Grafting in ThE LARGE Grasses.-Successful grafts. were obtained in Merker grass, Pennisetum purpureum Schum. var. merkerii; bamboo, Bambusa longispiculata Gamble ex Brandis; sugarcane, Saccharum offcinarum L.; guinea grass, Panicum maximum Jacq.; and Para grass or malojillo, Panicum purpurascens Raddi.

The graft union in Merker grass.--The Merker grass was found to be easiest to work with, because it gave a smooth, even surface when the stem was ruptured and consistently formed a relatively high percentage of successful unions. Most of the grafts were with this plant, to obtain a complete series of the various stages in union. Sufficient work was done with the others to show that the pattern of vascular union was the same. In Merker grass 8.0 per cent success was obtained when scions were exchanged and 17.8 per cent when the same scion was replaced. An average of 34 per cent was obtained with the other species.

Photomicrographs of the stages of union are shown in fig. 1-4. The earliest stage at which the grafts could be examined after grafting without causing separation was 10 days, although they were still very brittle and had to be handled with care. At this time, a thin, dark layer was found between stock and scion. This may have been the result of oxidation in the surface of intact cells exposed to the air or of the deposition of wound gum. In some stocks and scions it appeared to contain the remnants of cells injured when the break was made. Since this darkly stained layer appears at the junction of the scion and stock where they are held in contact, we are calling it the contact layer. A similar layer formed in portions of the stem which were ruptured in grafting although not exposed to the atmosphere. Artschwager (1951) called a similar layer in dicotyledon grafts the contact layer.

After the formation of the contact layer, the parenchyma cells in both scion and stock adjacent to this layer enlarged as shown in fig. l. Subsequently, they divided and regained approximately normal size and the contact layer disappeared in certain areas (fig. 2, 3). This occurred especially between vascular bundles. Some of these new cells then became thick-walled and pitted to form short, oblong tracheids which united the vascular bundles. An early stage in union is shown in fig. 4 , where the differentiation of parenchyma cells into tracheids was partially completed. Some of the new cells remained thin walled and apparently united the phloem. Differentiation did not progress at the same rate over all portions of the graft. Remnants of the contact layer persisted at least 8 months and the process of vascularization lagged in some areas. Several tiers of cells on the scion and stock adjacent to the union, became thick-walled and pitted. Within 3 months after grafting, these tissues became very hard and extremely difficult to section. Cross sections above the union (fig. 5) and through the union (fig. 6) demonstrate this response clearly. A 6-month-old graft (fig. 7, 8) shows the excellent vascular connection and the thick-walled cells along the edges of the graft union. The mechanical strength of this tissue is demonstrated by the fact that this stem was broken by wind, not at the graft, but several inches below the graft union. At this time it had made approximately $70 \mathrm{~cm}$. of new growth. Photographs of this stem and a younger one are shown in fig. 9 and 10 .

For about 6 weeks after grafting, the scions did not grow. After this time they put out a few new leaves within the next 3-4 weeks. Stem growth seldom occurred before 2-3 months had elapsed, but in some grafts it was very rapid after this time. The rate of growth varied considerably among grafts of the same age and appeared to be correlated with the amount of vascular connection. For example, a number of grafts were found which united less than half of the cross-section of the stem, but managed to survive for several weeks. They put out a few new leaves, but failed to elongate to any extent.

If the buds on the stock were allowed to grow, the scion sometimes remained green for some time but apparently was unable to compete with the: sprouts from the stock and eventually withered and died.

Numerous authors, among them Eames and MacDaniels (1947), and Artschwager (1951), have suggested that the differentiation of callus parenchyma cells in a graft union in dicotyledons is related to the nearness of vascular bundles, but be- 


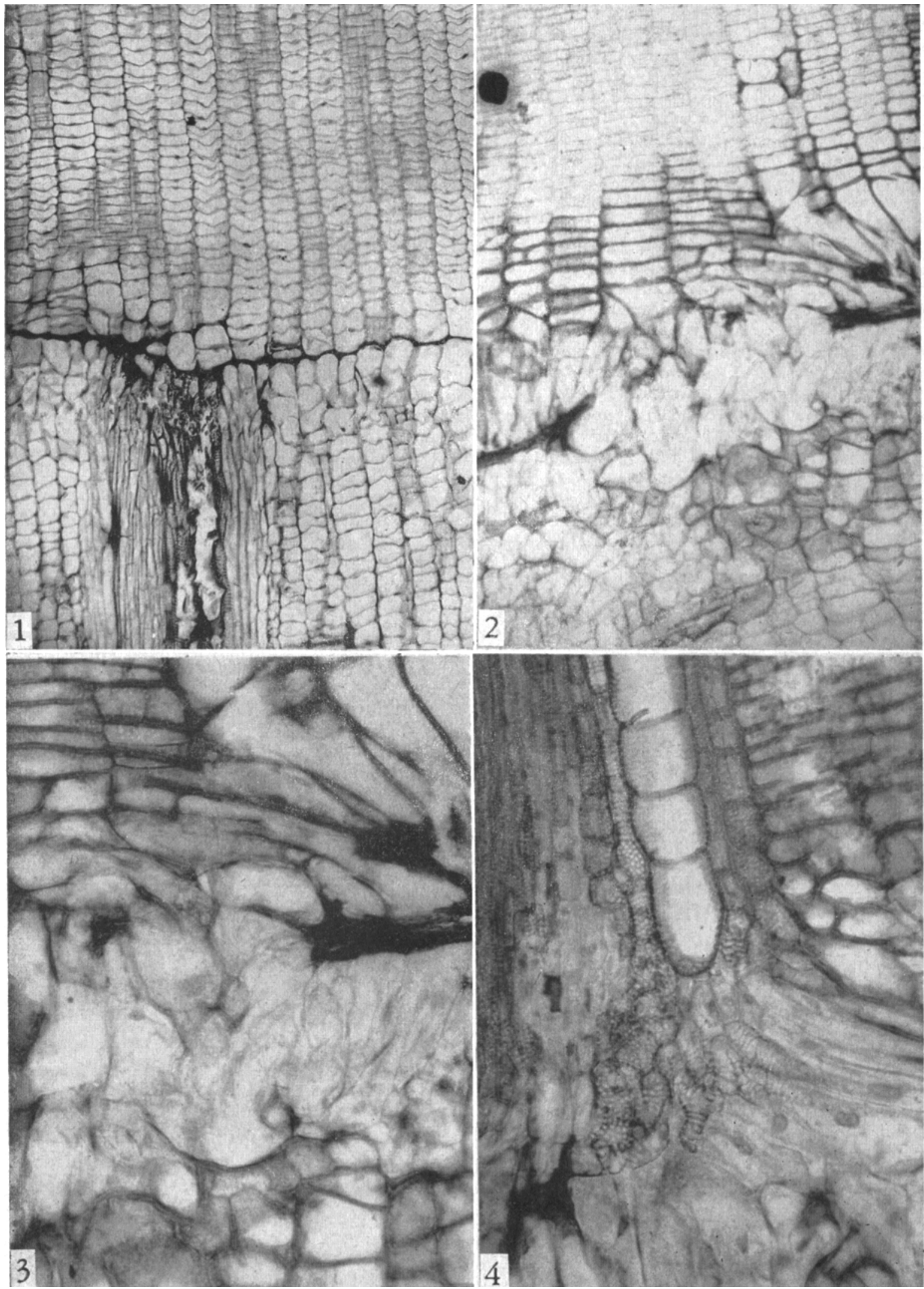

Fig. 1-4. Legend on page 452. 


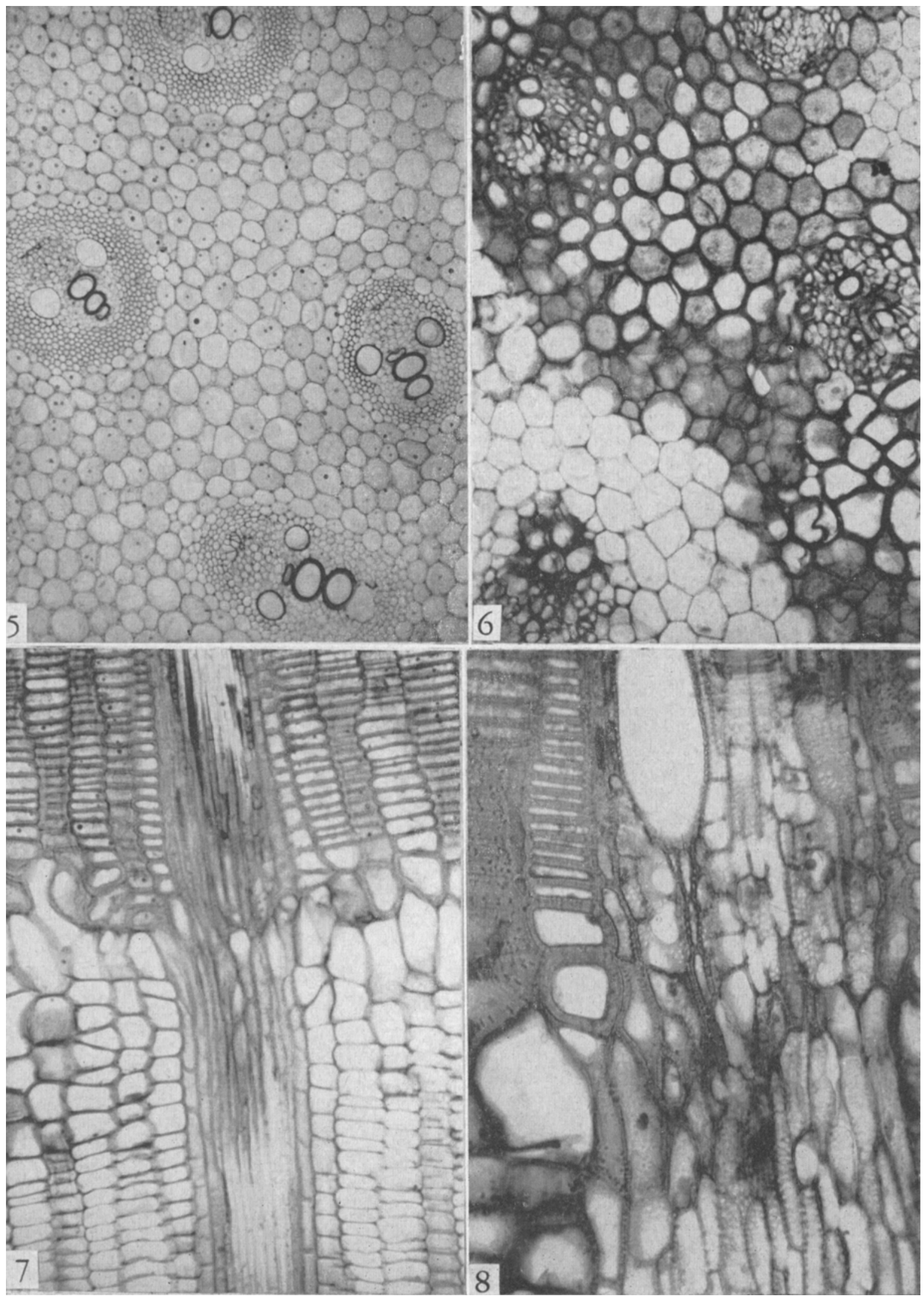

Fig. 5-8. Legend on page 452 . 


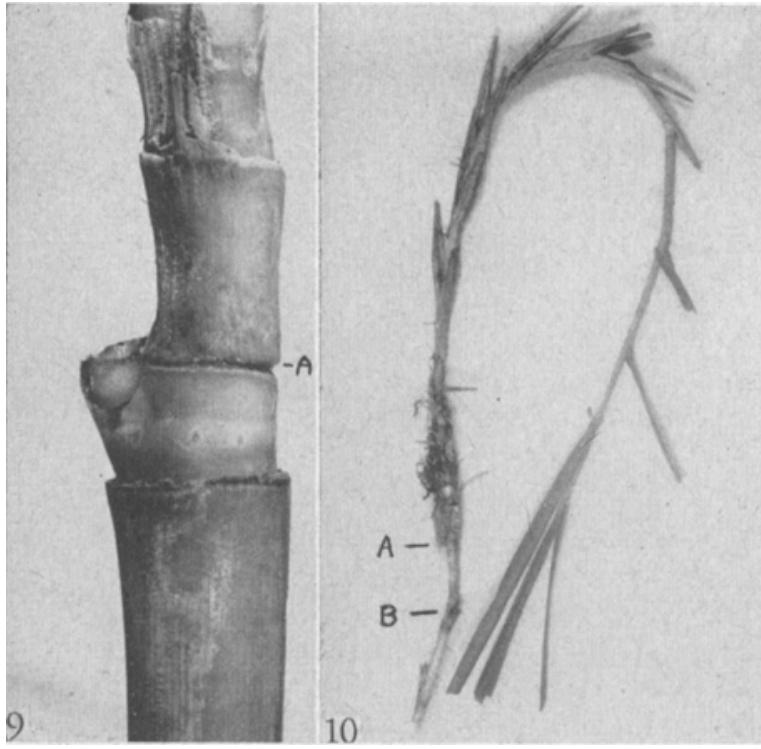

Fig. 9-10. External appearances of graft unions in Merker grass.-Fig. 9. Merker grass, 6 weeks after grafting. Union shown at (A).-Fig. 10. Merker grass, 6 months after grafting. Graft union shown at (A). Approximately $70 \mathrm{~cm}$. of stem was new growth. Stem broken (B) by wind below union.

cause of the proximity of so many vascular elements, no conspicuous correlation is noticeable. Bloch (1952) has reviewed the literature on regeneration of vascular strands in wounds. The regenerating strand formed in a polar fashion from the upper margin to the lower part of the cut and the evidence suggests that histological differentiation frequently involves the establishment of intercellular fields or patterns.

The influence of vascular tissue on the differentiation of parenchyma cells was clearly shown in many grafts of monocotyledons. When the scion was replaced in such a way that the vascular bundles were in close proximity but not exactly in juxtaposition, the path of transformation of parenchymatous cells into tracheids which united the vascular bundles of stock and scion was a curve and not a straight line.

Graft unions in other grasses.-Although our earliest success was obtained with Bambusa longispiculata, later work has been disappointing. One graft grew very rapidly, after a period of 6 weeks after grafting, reaching a height of $10 \mathrm{ft}$. in 11 months. On the other hand, several other grafts failed to grow at all over the same period. Attempts were made to graft several other bamboo species, with no success. Temporary unions were obtained on Phyllostachys but no permanently successful grafts were made except on $B$. longispiculata. The only successful grafts on this plant, over a 2-year period of trial, were obtained in April just at the beginning of the wet season, indicating a possible seasonal effect.

Some grafts were also made on surgarcane which was rather difficult to work with because it frequently ruptured unevenly and left jagged edges. The leaf blades are barbed, and must be handled discreetly. Union occurred as in the other grasses. Successful grafts were also made with Para grass and guinea grass, including a graft of a young flower shoot on another shoot in guinea grass.

Intergeneric graft unions in the grasses.-Many attempts were made to make grafts between various genera among the grasses, using Merker, Para grass, sugarcane and guinea grass. Only a few grafts of Para grass on Merker grass were success. ful. Small side shoots from the Merker grass were chosen as stocks and vigorous Para grass shoots as scion material. The scions survived for several months, growing several $(30-40) \mathrm{cm}$., and flowering and setting fruit.

Grafts With Lianas.--Various species of monocotyledonous lianas are conspicuous parts of the tropical landscape. The Solomon Islands ivyarum,

Fig. 1-4. Early stages of graft union in Merker grass.-Fig. 1. Longitudinal section of the graft union in Merker grass, 20 days after grafting. Contact layer visible as dark lines between scion and stock. Note enlargement of cells next to contact layer.-Fig. 2. Partial disappearance of contact layer and cell division adjacent to contact layer.Fig. 3. Close-up of fig. 2 showing proliferating area. Dividing cells are thin-walled with large nuclei. Cells above and below are becoming thick-walled and pitted.-Fig. 4. Differentiation of parenchyma cells into short, thick-walled pitted tracheids to join vascular bundles. Process about one-half complete.

Fig. 5-6. Later stages of graft union in Merker grass.-Fig. 5. Cross-section through stem about $1 \mathrm{~cm}$. above graft union. Parenchyma cells between vascular bundles are thin-walled.-Fig. 6. Cross-section through same stem, in region of graft union. Notice thickening of parenchyma cells between the vascular bundles.-Fig. 7. Longitudinal section of graft union, approximately 6 months after grafting. Vascular connection appears excellent. - Fig. 8. Section through center of vascular bundle, 6 months after grafting to show union in the center of the vascular bundle. Some cells apparently remain thin-walled and unite the phloem.

Fig. 11-14. Graft unions in the lianas.-Fig. 11. Union between Scindapsus aureus and Nephthytis afzelii. Disappearance of contact layer and "invasion" by parenchyma cells. Note that callus tissue formed was much more extcnsive than in the grasses studied.-Fig. 12. Close-up of fig. 11. Note large nuclei in the invading parenchyma cells.-Fig. 13. Differentiation in Scindapsus aureus of new tissue between vascular bundles. Six months after grafting. Union between bundles completed.-Fig. 14. External appearance of grafted Scindapsus aureus plant 6 months after grafting. All the stem portion with leaves is new growth made after grafting. 


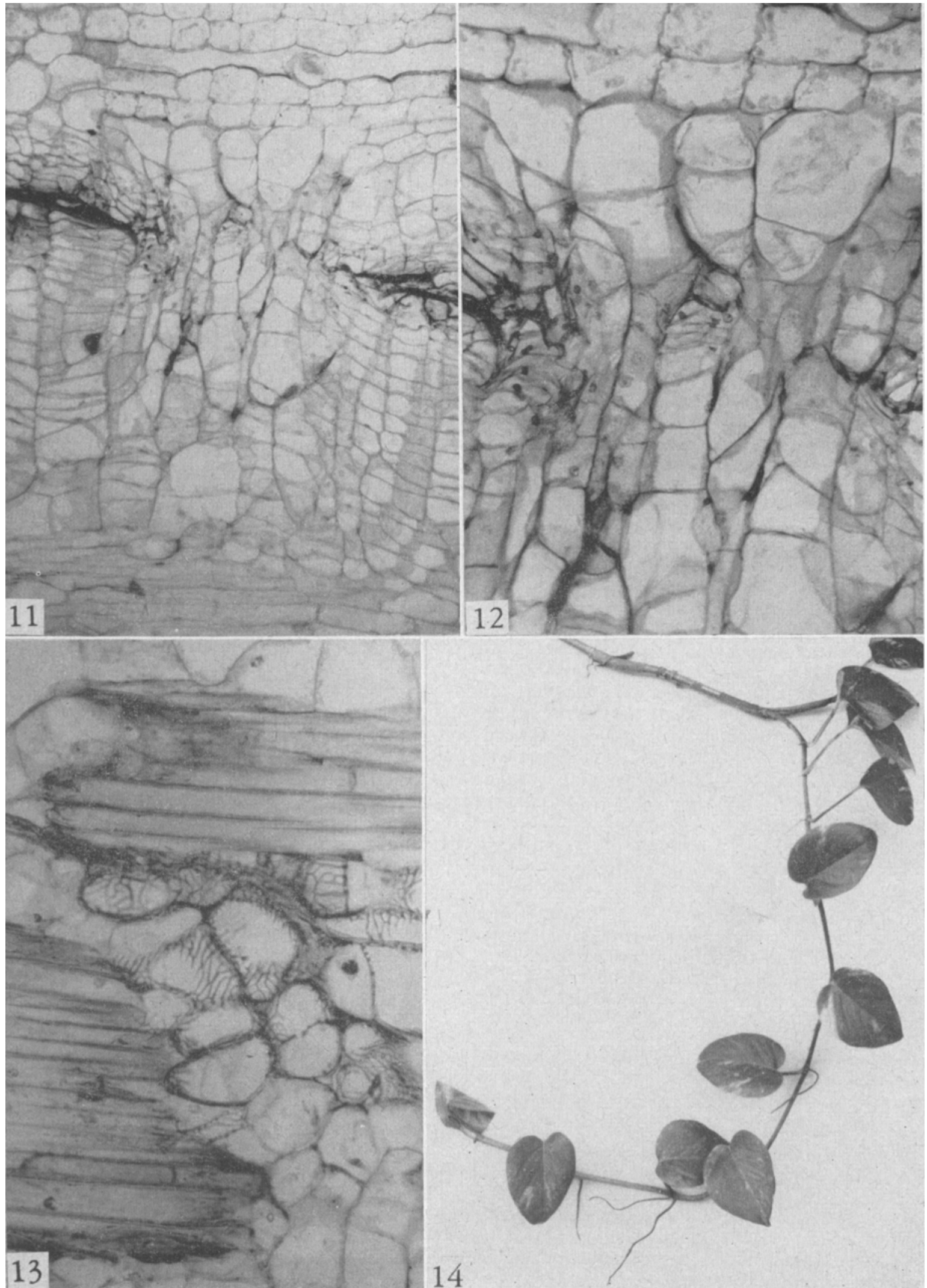


Scindapsus aureus (Lindl. and Andre) Engl., was used in most of the experiments. Philodendron nachodomi Britton and Nephthytis afzelii Schott were also tested on a smaller scale. A remarkable amount of callus was formed by these stems, if cut in a meristematic region: a rather unusual activity in monocotyledonous plants which generally regenerate very poorly. This ability was first noticed in some tissue culture experiments in which large masses of callus were formed by stem pieces.

The union of stock and scion in these lianas followed the same general pattern as previously described in the large grasses; the main difference was in degree. A contact layer and a band of parenchyma tissue formed as in the grasses, but the cell division appeared to take place at a greater rate and for a longer time. In the initial stage, there was a considerable enlargement of the cells adjacent to the contact layer, followed by division of these cells. There were approximately 20-30 tiers of new cells formed as compared to $3-5$ in the grasses. Differentiation of vascular tissue occurred in 3-4 months and during this period growth was very slow. After that time, growth was frequently very rapid; some scions attained a length of 4-5 ft. in 6 months. It may be remarked that union did not always occur over the entire cross-section of stem and growth of scion was obviously limited in cases where the union was only partial. For example, in one instance, the union occurred over half of the stem only. The graft survived for many months. Only a few inches of new shoot growth were made as compared to the several feet in other grafts. Union over approximately one-half the cross-section seems to be the lower limit which will support the scion.

The relative ease of grafting of these lianas as compared to the grasses led to investigations of intergeneric grafts. Grafts of Nephthytus on Scindapsus were about 15 per cent successful. The process of union is very similar to that when Scindapsus was used as both scion and stock. Various stages in union in these lianas are shown in fig. 1-13. A grafted plant is shown in fig. 14 . About 8 months after the intergeneric grafts were made, a dry season of unusual length and duration occurred. The scions died back 2-3 in. and lost their leaves and it was thought for a time that they were lost. However, with the coming of the rains, they again resumed growth and appeared healthy. During this period the grafts of Scindapsus on Scindapsus retained all their foliage and remained completely green.

\section{SUMMARY}

Successful grafts of several monocotyledonous plants are described. Grafts were made in five species of grasses and also a few intergeneric grafts in this group. Grafts between some of the large tropical lianas were made also. Intergeneric unions were obtained between Nephthytis afzelii and Scin- dapsus aureus. These results demonstrate that many monocotyledonous plants can be grafted and follow a regular process of regeneration and union, formation of a contact layer, enlargement of cells next to this layer, division of these cells, disappearance of the contact layer between vascular bundles. The influence of the vascular tissue on proliferation and differentiation of parenchyma cells was clearly shown since union of the bundles frequently occurred in a curve rather than a straight line. The process of union in the grasses and lianas is essentially very similar, differing primarily in degree. Cell enlargement is greater in the lianas and more callus is formed, and a greater period is required for the union of scion and stock. The process of union in the intergeneric grafts of the lianas is slower and less complete than in the grafts of a species on itself as demonstrated by the fact that the scions on the intergeneric grafts lost their leaves and died back partially during a dry season which occurred 8 months after they were grafted, whereas the intraspecific grafts retained all their foliage. One of the surprising revelations of this work was the relative ease with which some monocotyledonous plants could be grafted, providing that intercalary meristem is used. Some of the lianas do not show any intercalary meristem but have remarkable ability to form callus which enables unions to take place. Schubert cites numerous efforts which have been made without any success and it is somewhat surprising that he himself failed to get any vascular unions in species of which the scions were able to remain alive for months. Probably many other species of monocotyledons will be grafted in the future and although the process seems to offer no economic use at the present time, in this group of plants it may prove very useful in experimental studies.

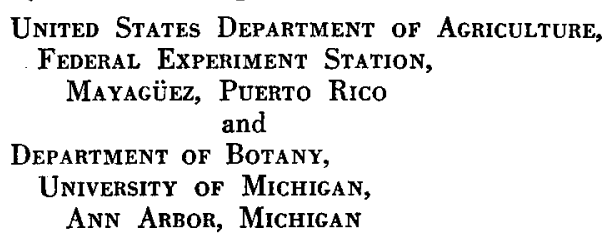

\section{Literature Cited}

Artschwager, E. 1951. Anatomical studies on graft unions between guayule and sunflower. (In interspecific and intergeneric grafts with special reference to formation of rubber in guayule). U. S. Dept. Agric. Tech. Bull. 1040.

BLoch, R. 1952. Wound healing in higher plants II. Bot. Rev. 18: 655-679.

Calderini, I. 1846. Essai d'expériences sur la greffe des Graminées. Ann. Sci. Nat. Bot. III. 6: 131-133.

Eames, A. J., ANd L. H. MacDaniels. 1947. An introduction to plant anatomy. McGraw-Hill Book Co. New York.

LA RuE, C. D. 1944. Grafts of monocotyledons secured by the use of intercalary meristems. (Abstract) Amer. Jour. Bot. 31 (8, suppl.) : 3-4. 
- AND FERN Reissig. 1946. Grafting in leaves. Amer. Jour. Bot. 33: 220.

Muzik, T. J., and C. D. La Rue. 1952. The grafting of large monocotyledonous plants. Science 116: 589-591.

Plotnikov, T. S. 1939. The technique of grafting grain crops. Jarovitzatzia $3(24): 63-65$.
Schubert, O. 1913. Bedingungen zur Stecklingsbildung and Pfropfung von Monokotylen. Centrabl. Bakt. II Abt. 38: 309-443.

Transeau, E. N., H. C. Sampson, and L. H. Tiffany. 1947. Textbook of botany. Harper \& Brothers. New York.

\title{
THE DETECTION AND NATURE OF DOMINANT LETHALS IN LILIUM. I. EFFECTS OF $X$ RAYS ON THE HERITABLE COMPONENT AND FUNCTIONAL ABILITY OF THE POLLEN GRAIN ${ }^{1}$
}

\author{
Spencer W. Brown and Marion S. Cave
}

DOMINANT LETHAL FACTORS are those which prevent, under usual environmental conditions, the development of the zygote in which they first occur. Originally recognized by Muller and Settles (1927) in a study of translocated chromosomes in the fruit fly, Drosophila melanogaster, dominant lethality was shown to be the result of genetic unbalance in the zygote, with some chromosome regions present three times, others, only once. However, a gamete carrying an unbalanced chromosome set functioned normally and gave rise to a viable zygote when united with another gamete carrying the complementary unbalance.

In higher plants, the presence of the gametophytic generation may preclude the transmission of unbalanced complements. Although both the male and the female gametophytes are fairly tolerant of additions to the single set of chromosomes, as in trisomics and duplications, the male gametophyte is particularly sensitive to deficiences and will transmit only relatively small ones (Creighton, 1934, 1937; McClintock, 1944; Burnham, 1932; Smith, 1948). It seems unlikely that a degree of genetic unbalance tolerated by a haploid gametophyte would prove lethal when combined with a normal complement in a diploid zygote. As a rule, it is therefore not possible to study, in higher plants, predictable types of dominant lethal factors arising as meiotic segregation products.

As was first demonstrated by Muller (1927), another source of dominant lethal factors is to be found in the use of mutagenic agents. In animals, it has been clearly recognized (Stancati, 1932; Maxwell, 1938) that apparent zygotic failure would result from inactivation of sperm by the mutagenic agent as well as by induction of dominant lethals. Embryological studies of D. melanogaster by Demerec and Kaufmann (1941) and of Sonnenblick (1940) have shown, however, that treatment of sperm with doses of $X$ rays resulting in nearly 100 per cent failure of eggs to hatch

\footnotetext{
${ }^{1}$ Received for publication December 14, 1953.

These studies were aided by a contract between the Office of Naval Research, Department of the Navy, and the University of California, Project NR 164 128. The authors acknowledge with thanks the technical assistance of Miss Pauline Shapard, Mr. Donald Stone, Mr. George Brosseau, Dr. Dale Steffensen, and Mr. Daniel Zohary.
}

still does not prevent fertilization. Likewise Henshaw (1943) demonstrated that frog sperm retains its ability to fertilize at doses many times greater than those required to prevent normal growth and differentiation of the embryo.

In plants, the complex nature of the germination and growth of the pollen grain and tube have made unwarranted the assumption that the mutagenic agent does not affect these activities. Thus it has not been possible, in studies of mutation, to distinguish between dominant lethality and failure of fertilization except for those seeds in which the presence of some tissue gives evidence of fertilization (Stadler, 1931, 1939; Stadler and Sprague, 1936).

In the present report it will be demonstrated that treatment with at least one mutagenic agent, $\mathrm{X}$ rays, at doses sufficiently high to cause almost 100 per cent dominant lethality, has no appreciable effect on the functioning of the pollen grain and does not prevent fertilization. In addition, most of the dominant lethals produced are manifested by the complete abortion of the seed.

Whiting (1937) has pointed out that the recognition of dominant lethals would afford a highly efficient means of testing the efficacy of a presumptive mutagenic agent. Inasmuch as the production of mutations would result in an immediate failure of the zygote to develop, there would be no need for elaborate tests of progeny.

A method for detecting dominant lethals in lily was first considered, in collaboration with Dr. Nirad K. Sen, as a desirable means of determining the efficacy of various chemical mutagens as applied to higher plants. The abundant stigmatic fluid of the lily assured successful development of pollen grains which had been handled in aqueous solution (Brown and Cave, 1953). The well-known mutagenic agent, $X$ rays, was chosen for the original studies for several reasons. It seemed desirable to use the agent that might be expected to give the most clear-cut results for the demonstration of dominant lethality in higher plants. Obviously, trials with less well-known agents, as some of the apparently poorly effective chemical mutagens, would have more meaning if the procedures, themselves, had previously been investigated thoroughly 